\title{
A Management Framework of Islamic Micro Financing for Sustainable Oil Palm Farming
}

\author{
Mohd Adib Ismail* \\ Universiti Kebangsaan Malaysia, Malaysia \\ Sukainah Farhah Ador \\ Universiti Kebangsaan Malaysia, Malaysia \\ Muhammad Hakimi Mohd Shafiai \\ Universiti Kebangsaan Malaysia, Malaysia
}

\begin{abstract}
The growth of demand and production in palm oil has increased rapidly from time to time, as this scenario has a positive influence on economic development. However, in the long run, the scenario may give negative impacts on environment if it is not closely controlled. Therefore, this study aims to create a sustainable mechanism framework of palm oil farming among smallholders using Islamic micro financing. This is because the position of smallholders is an issue in the sustainability debate in the palm oil industry at the global level. Using library research approach, this study discovered the constraints and the challenges faced by independent smallholders to create sustainable oil palm farming. Hence, the study was developed around the specific objective that looked into the Islamic microfinance form and proposed an appropriate mechanism for the implementation. In doing so, this study employed the descriptive method. From the results, it was concluded that Islamic microfinance is indeed a possible source of funding for a number of independent oil palm smallholders. Later on, Islamic microfinance may contribute to sustainable palm oil production. Furthermore, by introducing a workable mechanism, more Islamic financial institutions should be involved in providing Islamic microfinancing to smallholders.
\end{abstract}

Keywords: microfinance, sustainability, oil palm, independent smallholder

\section{INTRODUCTION}

The demand for palm oil and its production have increased rapidly. Currently, palm oil production has dominated the edible fat categories. Furthermore, palm oil has multiple usages for both food and energy sectors (Tincliffe, H., Webber 2012).

\footnotetext{
*Email: mohadis@ukm.edu.my Received : 19-12-2018, Accepted : 26-12-2018, Published : 30-12-2018

P-ISSN : 2087 - 9954, E-ISSN : 2550 - 0066. DOI:http://dx.doi.org/10.26418/jebik.v7i3.30200
} 
Furthermore, Malaysia and Indonesia together produce more than 80 percent of world production, where between 35 and 40 percent of land use is owned by smallholders. They collectively contribute to about 33 percent of the total output (Vermeulen, S., Goad 2006). These scenarios contribute to a positive impact on the development of this sector and it is able to increase the GDP of the country. However, in the long run, this may end with negative impacts if it is not closely controlled, such as environmental degradation and income inequality. These problems are common issues among small-scale and ineffective farms (Rahman, A.K.A, Abdullah, R., Shariff, F. M., Simeh 2008). In addition, these farms are owned by smallholders.

In fact, smallholders are classified as a major player in the palm oil sector (Vermeulen, S., Goad 2006). Globally, around 3 million smallholders are involved in this sector (RSPO 2010 ; Teoh 2010). Besides, there are three categories of smallholders which are supported smallholders, collective landowner schemes, and independent smallholders (Vermeulen, S., Goad 2006). In Malaysia, out of the total of 4.49 million hectares planted under oil palms in 2008 , encircling 30 percent was under 'scheme' or organized, while almost 11 percent was managed by independent smallholders. However, the current paper focused on independent smallholders. The independent smallholders are those who are self-organized, self-financed, and have more autonomy to choose how to use their lands, which crops to plant, as well as how to manage them. They are not contractually bound to any particular mill or alliance, although they may receive support or extension services from government agencies (RSPO 2010). At the same time, they sell their crops to local mills either directly or through traders.

These independent smallholders usually have small-scale production entities, as compared to the large-scale production system commonly owned by companies. Even though it is small in terms of average production; these independent smallholders have played a significant role in the development of the agriculture sector. Furthermore, the cumulative size is relatively large. Hence, their contribution to the production volume cannot be ignored.

According to Rahman, A.K.A, Abdullah, R., Shariff, F. M., Simeh (2008), the independent smallholders are unorganized smallholders that are not bound to any plantation scheme. This situation has led them to receive limited external assistance in the form of training, credit services, seedling, fertilizer, and so on. This causes their farms to be inefficient and unproductive (Rahman, A.K.A, Abdullah, R., Shariff, F. M., Simeh 2008). Hence, they produce lower quality crop. Furthermore, they are unlikely to benefit from a direct relationship with local mills, as they often rely on traders to purchase and transport their fresh fruit bunches (FFB) to the mills and have no guarantee regarding the price that will be paid for their crop. That makes them to cultivate their oil palm through an improper way. This may result in many negative effects to the environment, economy, and society. As a result, the improvement of productivity and sustainability must be made. 
Moreover, between 1980 and 2000, palm oil production increased by more than 400 percent and this scenario has been forecasted to continue (Koh, L.P., Wilcove 2007; Nilsson 2013). Meanwhile, from the environmental perspective, the increase has led to concerns about its impacts on natural habitats, biodiversity, and also climate (Fargione, J., Hill, J., Tilman, D., Polasky, S., Hawthorne 2008 ; ADB 2008). Furthermore, it may cause other consequences, such as increase in land erosion, loss of biodiversity, increase in fire risk, and so on (Naidoo, R., Malcolm, T., Tomasek 2009). On the other hand, the effects from the economic perspective assert that the increase may provide sources of income for many farmers, specifically the smallholders. However, the increase may not last long, as in the long run; the benefit is still subject to uncertainties because unsustainable cultivation of oil palm may expose farmers even more to future price fluctuations (Rist, L., Feintrenie, L., Levang 2010).

In this regard, independent smallholders would encounter a number of constraints in maximizing their potentials in palm oil production while maintaining independent choice and autonomy. Besides, the position of smallholders is debated due to the sustainability of the palm oil industry. Furthermore, social NGOs have often highlighted the sustainability of independent smallholders concerning palm oil production to be achieved due to environmental issues. Therefore, in order to achieve sustainable palm oil production among these smallholders, financial aid is an important aspect in the realization of this aim. Besides, in Malaysia, numerous financial assistances have been provided for the palm oil industry in many aspects and at each level of palm oil production. However, financial assistance for small farmers is inadequate, especially for independent smallholders. Thus, this study is aimed to create sustainable framework of palm oil farming among smallholders using Islamic microfinancing. The research questions have arisen from this study are: What are the constraints or challenges faced by smallholders of palm oil to create sustainable palm oil production? What type of mechanism can be developed to help independent smallholders to achieve the objective?

Therefore, this study is aimed to discover the constraints and the challenges faced by the independent smallholders to create sustainable palm oil farming. Besides, this study is to attempt to advocate a form of financing assistance mechanism as a fundamental to create sustainable palm oil production. With that, the Islamic microfinance instrument had been employed to achieve this goal. For the purposes, this paper employs descriptive approach using library research method to review past studies and propose a funding mechanism that may benefit smallholders.

This study is indeed significant as it promotes sustainable palm oil production through Islamic microfinance instrument as the financing assistance mechanism. Hence, the independent smallholders would be able to create sustainable oil palm farming. They should benefit from the mechanism in terms of increment in yield, knowledge, profit, and so on. Furthermore, the mechanism at wider aspect may positively benefit the environment and society as a whole. Besides, this study also provides the policy maker 
an option on how to promote sustainability, as well as to provide financial assistance to smallholders. Lastly, this study contributes to the literature review in this area.

The paper is organized as in the following. The next section is the literature review and the research gap, followed by results and discussion on the constraints and challenges, the emergence of microfinance institutions, the proposed mechanism and fund management model, and finally, the conclusion.

\section{LITERATURE REVIEW}

The smallholders include those who participate in collective landowner schemes (Vermeulen, S., Goad 2006), supported smallholders, and independent smallholders (Ismail, A., Simeh, M. A., Noor 2003; Vermeulen, S., Goad 2006; Rahman, A.K.A, Abdullah, R., Shariff, F. M., Simeh 2008; Omar, I., Dahari 2009; Dahari, N., Omar, I., \& Mansor 2010). Collective landowner schemes are a lease or joint venture contract, whereby local landowners who hold land title rent out their land to a plantation company. They collect shared profit based on the equity value of their land, which is defined as mini-estate or Konsep Baru in East Malaysia (Vermeulen, S., Goad 2006).

On the other hand, referring to (Ismail, A., Simeh, M. A., Noor 2003), supported smallholders are those who get direct support from the government or the private sector, in term of setting up farms, input supply, and so on. In Malaysia, several agencies like Federal Land Development Authority (FELDA), Federal Land Consolidation and Rehabilitation Authority (FELCRA), and Rubber Industry Smallholders Development Authority (RISDA) aid the smallholders in the oil palm sector by providing supporting programs and agricultural scheme. Meanwhile, independent smallholders do everything, all by themselves with minimal government assistance (Omar, I., Dahari 2009; Dahari, N., Omar, I., \& Mansor 2010).

It has been revealed that the productivity of independent smallholders is low (Abdullah 2013). The amount of production is far below the potential yield capacity of 10 tons of oil per hectare, where only between 3 and 4 tons per hectare are produced by smallholders (Murphy 2014). However, the study argues that the output may further increase if these smallholders utilize inputs more efficiently. In fact, several steps can be taken to increase the yield and income of smallholders. The steps include to reduce cost of production, to integrate palm oil with other crops rotation and livestock integration, to use quality inputs and manage inputs with proper management, to provide training for smallholders, etc.

Production costs can be reduced through co-operation among the independent smallholders (Rahman, A.K.A, Abdullah, R., Shariff, F. M., Simeh 2008). Other than that, integrating palm oil with other crops rotation can be done through the process of replanting, such as integration with sweet potatoes, corn, and groundnuts (Tohiran, K. A., Raja Omar, R. Z., Omar, W., \& Johari 2010). Meanwhile, livestock integration, such 
as sheep and cows, could be made if the oil palm trees are above 5 years old (Tohiran, $\mathrm{K}$. A., Raja Omar, R. Z., Omar, W., \& Johari 2010). The benefits of both types of integration are that they are able to optimize the use of land, generate additional revenue, and maximize the income of smallholders (Tohiran, K. A., Raja Omar, R. Z., Omar, W., \& Johari 2010). Then, the quality of production inputs, such as seedlings, balanced and adequate fertilize, etc. (Manaf, Z.A., Rahman, A.K.A., Halim, N.A.A., Ismail, S., Abdullah 2013), must be determined as well.

In addition, since the productivity of independent smallholders is currently inefficient; their farm management may also be environmentally challenging as they use inefficient methods of farming, such as open burning, excessive fertilizer, and pesticides. The practice may worsen the environment and it may affect the long run output. Thus, proper training for independent smallholders may be beneficial to increase farm yield and promote sustainable farming.

Even though the oil palm sector has contributed a lot to the economy based on annual national income and employment; there are a few negative impacts on the internal and external aspects if this sector is not managed properly, as it will affect the environment, the economy, and the society. Therefore, this sector must achieve sustainability to overcome these problems. Moreover, in the literature, the sustainable paradigm consists of three pillars; namely economic growth, environmental protection, and social dimension (Brandi, C., Cabani, T., Hosang, C., Schirmbeck, S., Westermann, L., Wiese 2013; Nilsson 2013; RSPO 2010). Kessler J.J., Rood T., Tekelenburg T. (2007) highlighted two indicators in the economic dimension, which are per capita gross domestic product, and employment rate.

Meanwhile, Kessler J.J., Rood T., Tekelenburg T. (2007) outlined that the indicators for social dimension are food security, child mortality, poverty index, vulnerability, conflicts, and inequality. Apart from that, the environmental dimension has many indicators, such as air, water, biodiversity (MPOB 2018), soil and agro-ecological management, etc. (Nelson P.N., Wbb, M.J., Orrell, I., Rees, H.V., Banabas, N., Berthelsen, S., Sheaves, M., Bakani, F., Pukam, O., Hoare, M., Griffiths, W., King, G., Carberry, P., Pipai, R., McNeill, A., Meekers, P., Lord, S., Butler, J., Pattison, T., Armour, J., Dewhurs 2010).

The current status and the future directions for the use of palm oil are so impressive. In fact, Basiron, Y., Weng (2004) stated that palm oil is not the only source used to produce food, but it has also been used in a widespread manner in non-food, biocomposite, and as nutritional products. On the other hand, palm oil is used in both food and energy sectors (Lam, M.K., Tan, K.T., Lee, K.T., Mohamed 2009); in which affirms that palm oil is the most often used oil to produce food.

Furthermore, as the smallholders are one of the major players in this sector, many previous studies have looked into smallholders. Recently, a number of studies have 
linked smallholders and sustainability as an important issue since sustainability has become a focus over global issues. The importance of sustainability aspects does matter for the development of the agriculture sector. In addition, the global debate did highlight the production of palm oil and its role in deforestation, biodiversity loss, climate change, and social conflicts (Rowell, A., Moore 2000; Teoh 2010). Thus, more attention has to be given to the issue of sustainable palm oil among smallholders.

However, studies pertaining to independent smallholders are still scarce in Malaysia. Furthermore, in terms of assistance, the scheme designed for smallholders and farms with a larger scale should be given more focus, such as FELDA. This research gap motivates the authors to review past studies to identify the constraints and the challenges faced by the independent smallholders in order to propose a form of financing assistance mechanism toward creating sustainable palm oil production.

\section{THE EMERGENCE OF MICROFINANCE INSTITUTIONS}

Access to the finance for the agriculture farmers is crucial. Without having access to the finance, it would be difficult for them to produce efficient amount of output on time. But yet majority of farmers in developing countries are excluded from the banking system. Furthermore, the interest rates charged by the banks are also unaffordable by the framers. In 1960s and 70s the rural finances were in control of public authorities. The objective was to develop the agriculture industry by modernizing it. This kind of financing was provided by government development banks and the donors from the credit markets with the flexible interest rates (Morvant-Roux 2008).

However, this system was costly and unsustainable and ultimately led to failure. When the problem was perceived it become known that a generous amount of fund was provided by the government and the donors to subsidize the interest rate and to cover the defaults that can arise because of unhealthy dependence on subsidies. The information regarding the borrower was first sent to the government and donors rather than informing the managers (Meyer 2007).

Since 1980s microfinance has become a vital part of the development, alleviating poverty and economic regeneration strategies around the globe. In early $21^{\text {st }}$ century, millions of people were availing the services from formal and semi-formal microfinance institutions (MFIs). It has emerged as a global industry which involves governments, banks, aid agencies and NGOs. Due to its emergence and expansion of branches, hundreds thousand people got the employment(Arun, T., Hulme 2009).

Microfinance was started in Latin America and South Asia as the poverty ratio in these regions is considered high. But it gained popularity from Bangladesh in 1976, following the wide-spread famine in 1974 (Yunus 2005). Supporters of this program argued that the microfinance scheme helped in poverty alleviation, improvement in schooling, and generated or expanded millions of small businesses. After the success of 
microfinance in Bangladesh, this idea spread in the other regions such as Africa, Latin America, Asia and Eastern Europe as well as in the developed economies like Norway, USA and England (Rahman, A.K.A, Abdullah, R., Shariff, F. M., Simeh 2007).

Access to the financial services is the right of every human being that enables him to avail an access to safe water, basic health services and primary education. Microfinance has emerged due to failure of the government in providing financing to the rural farmers (Hulme, D., Mosley 1996). The idea of micro financing has opened the ways for poverty alleviation because such kind of financing schemes are mostly uncollateralized loans that are provided to the poor as opposed the bank loan where the borrower must pledge an asset against the loan (Morduch 2009). The main feature of microfinance is the disbursement of small size loans to the micro entrepreneurs and the poor. The terms and conditions of such loans are more flexible as compare to the bank loan.

But due to the interest-based foundation of Microfinance Institution, it would be difficult for the farmers to payback the borrowed amount with interest. Secondly, due to the unpredictable nature of agriculture, it is not necessary that the farmer achieve the desire outcome as natural disasters may destroy the crops. In such case, it would be almost impossible for the farmer to return the borrowed amount. Thus, instead providing microcredit to the farmer, there is a need of profit and loss sharing mechanism in which none of the party should bear all the loss but to share it.

However, risk-sharing might not be a good option for Microfinance Institutions as they are responsible to pay back a return to the donors of the funds. It also has been seen in the past that due to lack of experience and lack of professionalism, the MFIs were failed to deliver what was expected from it (Morvant-Roux 2008). A study showed that microfinance institutes benefiting the creditworthy more as compare to destitute because they should earn profits to pay back the loan to the financiers with interest (Khaleequzzaman, M., Shirazi 2102).

In such scenario, the role of Islamic Microfinance become vital. It is the main objective of Islamic economy to help out those kinds of people who are not creditworthy. Islamic Microfinance Institutes have to follow Islamic ethics and the spirit of helping the people (Rahman, A.K.A, Abdullah, R., Shariff, F. M., Simeh 2007). Thus, it is necessary to meet the needs of these poor without any discrimination.

\section{CONSTRAINTS \& CHALLENGES FACED BY SMALLHOLDERS}

\subsection{Financial Assistance}

The primary constraint for smallholders is finance. They must bear the cost of production to cultivate oil palm on their own. Nevertheless, there is insufficient financial assistance to help them. Therefore, smallholders are not concerned about improving environmental performance. Instead, their concern is on maintaining their businesses as 
their only livelihood (Dubois 2008; Robinson 2000). Hence, they might adopt bad practice in their cultivation without knowing that it would give a negative impact on their yield and revenue. Even if they know the proper way to cultivate, the smallholders would still need financial capacity to practice good agricultural practice (GAP). With that, they have two options; either formal or informal borrowing assistance.

As for accessing bank loans, smallholders need adequate collateral in the form of land titles or their house certificates. Besides, some smallholders fail to meet the basic conditions of collateral, while some can only borrow a minimum amount of loan to secure bank financing. Other than that, in terms of access to capital, international and domestic banks do provide large loans to estates (Casson 2000), but this is not the case for smallholders. Furthermore, due to lack of credit worthiness, limited deal sizes for smallholders (IIED and ProForest 2004) cause them to be left behind in this sector. They also make informal loans so that they could bear the cost of production, such as obtaining loans from middlemen(Abas, R., Simeh, M.A., Abdullah, R., Hassan 2010) or from relatives and other sources.

\subsection{Cost of Production}

Production costs to be borne by smallholders include labor cost, material/inputs cost, and cost of transportation (Ismail, A., Simeh, M. A., Noor 2003). Labor cost comprises of costs of harvesting, collecting FFB, pruning, and so on. In addition, Rahman, A.K.A, Abdullah, R., Shariff, F. M., Simeh (2008) pointed out that the input costs involve costs of fertilizer, seedling, harvesting, and pesticide. The problem arises when the farmers try to reduce the costs due to financial restriction by applying insufficient amount of fertilizer, maintaining old oil palm, and harvesting unripe FFB.

The use of low-quality seedlings is also a major problem among independent smallholders (Thongrak, S., Kiatpathomchai, S., Kaewrak 2011). They also do not adhere to the schedule for fertilization. Moreover, the smallholders use pesticides without proper control and they do not handle it correctly. On top of that, other costs are low soil fertility, lack of knowledge in soil and fertilizer management, as well as the high price of fertilizer (Thongrak, S., Kiatpathomchai, S., Kaewrak 2011). Consequently, the independent smallholders in this industry are perceived to be inefficient and unproductive (Rahman, A.K.A, Abdullah, R., Shariff, F. M., Simeh 2008).

\subsection{Mill Access and FFB Dealer}

Independent smallholders are particularly exposed to crop price fluctuations risk. Monopsony purchase by mills and lack of bargaining power among smallholders worsen their problem (Vermeulen, S., Goad 2006). Often, they rely on dealers or middlemen to purchase and transport their FFB to the mills, besides having no guarantee regarding the price that will be paid for the crop (Nagiah, C., Azmi 2012). 
Furthermore, Rahman, A.K.A., Abdullah, Simeh, M.A., Shariff (2009) have outlined five elements of inefficiencies among the oil palm dealers, and they are: offering an oil extraction rate (OER) to smallholders without following standard procedures, dirty condition of the ramp, delay in conveying FFB harvested by smallholders, not offering a kernel extraction rate (KER) to the smallholders, and conveying unripe FFB. These actions could lead to unfairness and lower price received by the smallholders, and lastly, it also affects other players in the supply chain.

\subsection{Knowledge}

Knowledge of sustainable palm oil is still very low among smallholders. They are also unaware and do not understand the negative environmental impact of oil palm cultivation. Besides, independent smallholders have limited knowledge agronomic management skills in order to achieve higher yields (Euler, M., Hoffmann, M.P, Fathoni, Z., Schwarze 2016). Access to trustworthy information on prices and pricing policies, market opportunities, technical aspects of production and site management, as well as other fundamental rights and options under the national law or formal agreements, are also major difficulties faced by them (Vermeulen, S., Goad 2006).

In addition, most smallholders do not have any documentation pertaining to their farming activities due to lack of knowledge and failing to understand the advantages of recording and monitoring farming activities and finance. Hence, they would not know the actual costs incurred and the net profits received. Thus, in order to overcome knowledge gap, training is definitely needed, and it is a key factor in aiding smallholders to implement GAP.

\subsection{Global Market Condition}

Furthermore, smallholders also suffer from the condition of the global market. Demand for palm oil depends on their price compared to prices of other oil and fat substitutes for specific end uses, such as soybean, rapeseed, sunflower, cotton or coconut oils, in food and biodiesel applications. Moreover, abundant supplies of substitute crops and oils depress demand and cause price fluctuations of palm oil products (See Figure 1). For instance, a country that produces soybean will try to boycott palm oil entry into that country by imposing high taxes. Therefore, this sector is very closely interdependent to the chain in operation. Then, this will indirectly affect the smallholders. 


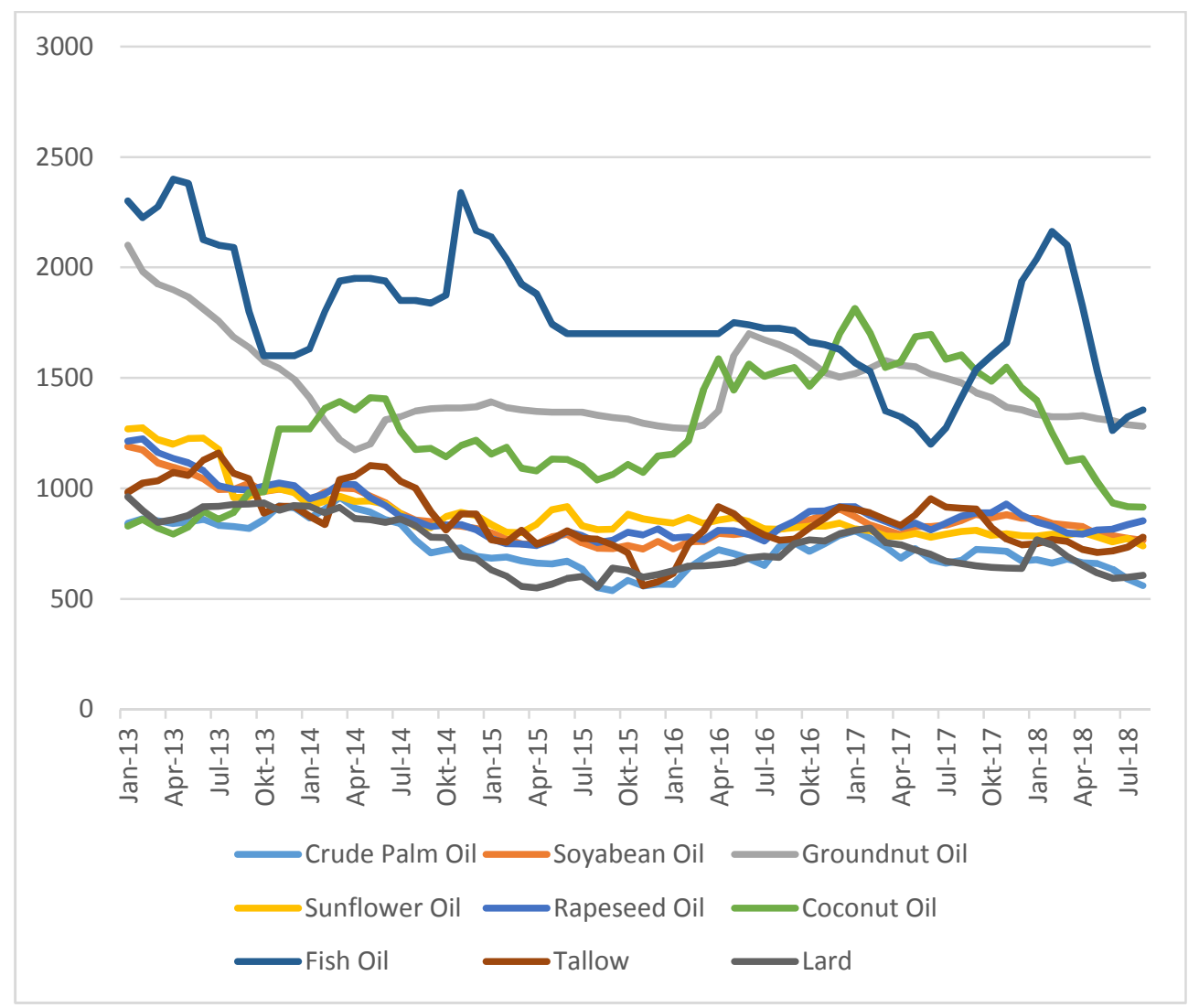

Figure 1. Prices of selected oils and fats (North-West Europe Market US\$/Tonne)

Source: MPOB Statistics

\section{MECHANISM FRAMEWORK}

Currently there is no organized mechanism framework to oversee the palm oil production among smallholders. Hence, this study proposes a sustainable mechanism framework that interlinks value chain of palm oil production and Islamic micro financing. The value chain is defined as a system that is made up of two components: 1) a sequence of activities, such as production, processing, and transport; and 2) a network of functional relationships that work together to reach an objective. These components interact through dynamic linkages, such as contractual arrangements and coordination, besides determining opportunities for investment along the value chain (Cromme, N., Prakash, A. B., Lutaladio, N., Ezeta 2010). This value chain mechanism involves various parties, such as NGO, independent smallholders, mills, islamic financial institutions, government agencies, etc. This value chain had been modified in order to provide financial and non-financial services to the target group. The modified mechanism is illustrated in Figure 2.

In Malaysia, Islamic microfinance that specializes in the oil palm sector is still inexistent. Therefore, in this mechanism, an Islamic microfinance institution that specializes in the oil palm sector is created. The institution is responsible to provide 
loans for selected groups of independent smallholders. Government agencies and MPOB cooperated to carry out the implementation of this mechanism. Besides, Islamic microfinance institution for an oil palm sector that has been established had been run in collaboration with entities involved in this mechanism. Moreover, a value chain approach involving public-private partnerships (PPPs) was applied in two funded Vegetable Oilseed Development Projects (VODP) by the International Fund for Agricultural Development (IFAD) (Mahieux, T., Zafar, O., Kherallah 2011). Hence, under the Islamic microfinance and all these entities, a stop center had been established. The uniqueness of this mechanism is the existence of the stop center.

Government agencies and MPOB conducted the selection of independent smallholders. Prior to selecting the locality of independent smallholders, the focus was on the locations with a lot of independent smallholders. After selecting a specific area, the entities involved selected the target population that met the inclusion criteria and this included those independent smallholders who were interested in the scheme. Then, the next step was the smallholders' agreement to abide by all terms and conditions. The selected independent smallholders were given explanation in detail about the mechanism, as well as the conditions for this scheme, such as the costs, benefits, risk, etc. Hence, it is a very important aspect to ensure that the procedure is in line with the concept of the contract, as required in Islam.

Meanwhile, the stop center serves to be one of the innovations in the value chain flow. The stop center integrates joint liabilities and decentralization approaches. The methods of direct loan and lending group, as implemented by the Amanah Ikhtiar Malaysia (AIM), is inappropriate for this situation due to the different widths of the farm for each independent smallholder, and there are also different needs for them to undergo development in order for them to become sustainable. In this vein, if the group lending approach is fully utilized, this will incur loss and injustice for the independent smallholders with limited land as compared to the others. Besides, the loan may also exceed the actual amount needed by the independent smallholders and the original objective of the loan given may be abused. In the end, it would only increase in the total amount of debt, but not the productivity or the revenue for the farmers involved, including the risk of default payment. However, if the group lending method is not used, high cost has to be covered by the fund provider in order to implement this mechanism. Therefore, the stop center is an alternative in resolving this problem. 


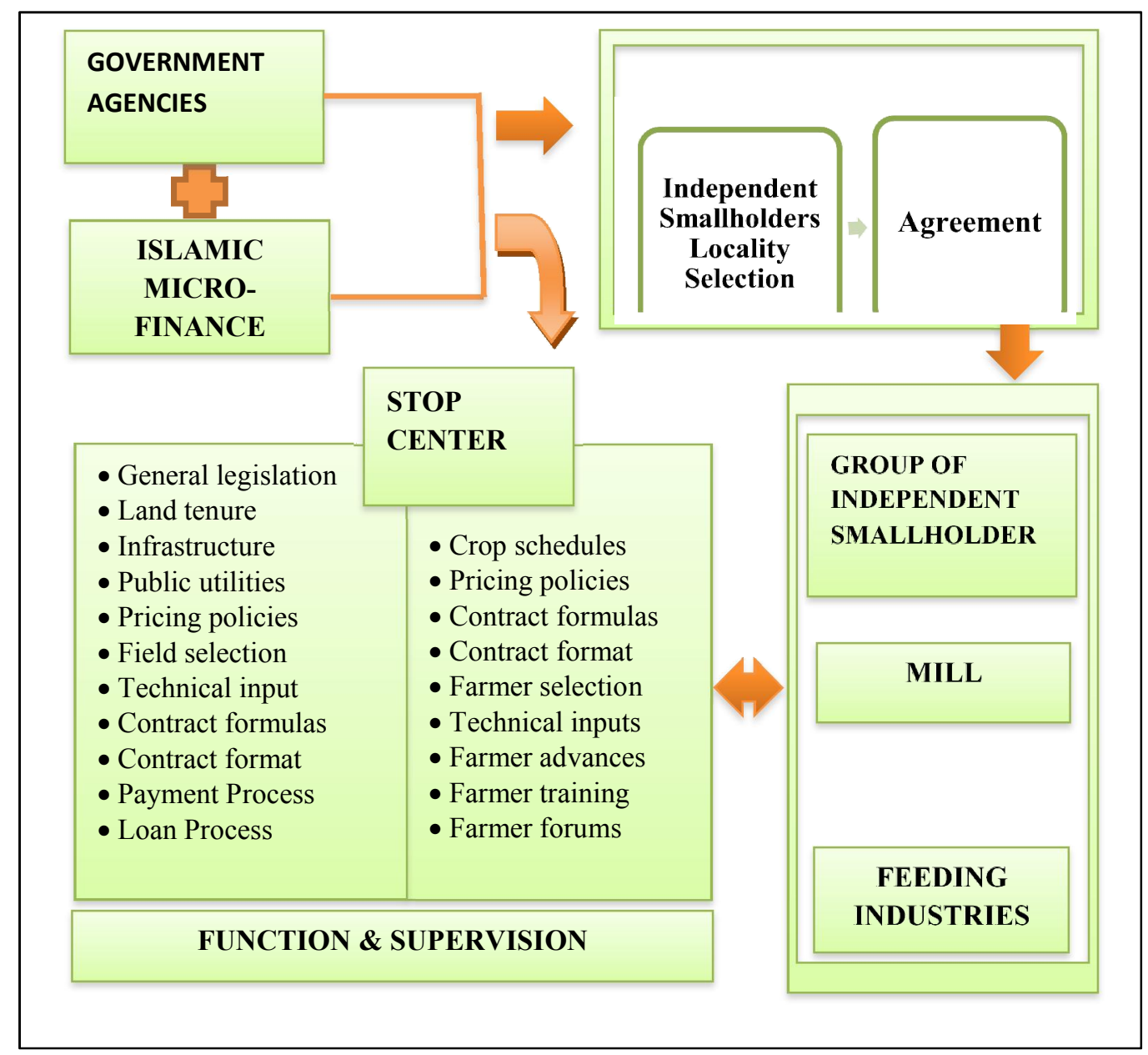

Figure 2. Value Chain Mechanism

Apart from that, according to Rahman, A.K.A, Abdullah, R., Shariff, F. M., Simeh (2008), the changing structure of oil palm smallholders is like using mini tractors for in-field transportation, co-operating among the independent smallholders, sending their own FFB to dealers, and using alternative inputs for maturing oil palm could reduce their cost of FFB production, overcome their problems, and also increase their income. Therefore, the stop center will prepare the facilities for the collective use for all independent smallholders involved. It will make the system more systematic, efficient, and more organized. The stop center will also supervise all the operations involved to ensure that it is in line with the objectives and the standard, such as pricing policies, contract, land tenure, etc. Besides, the representative of the entity, such as the group of independent smallholders, mills, and feeding industries, will supervise through the stop center. Moreover, the other functions of the stop center include:

i. Transportation: The stop center will prepare transportation, such as tractors, lorries, machinery, and many others. Lorries that are available at the stop center will be used to deliver fresh fruit bunches (FFB). 
ii. Accounting \& auditing: Total sale, profit, payment to mills, payment of total earning to independent smallholders, costs, and loan are noted and audited.

iii. Purchasing \& Shipping: The stop center will also supply quality pesticides, fertilizers, and seedlings based on the needs of the target group, and the price is also more reasonable due to wholesale purchases, as well as the seal of agreement between the suppliers concerned. The stop center will also deliver fertilizers, seedlings, and pesticides to all small-scale farmers based on the quantity needed by the farmers. This is to ensure that the pesticide used is controlled and only quality fertilizers and seedling are used for GAP to be executed by the group of independent smallholders.

iv. Facility: Provides storage of goods and other facilities.

v. Training: The professional instructors from MPOB will undertake the training for groups of independent smallholders concerning GAP and sustainable palm oil. Labor hired by each independent smallholder will also be trained here in order to comply with the sustainable standards.

Furthermore, in order to reduce the costs and save time, the feeding industries under the stop center play an important role in ensuring that the operation of this value chain runs smoothly. The stop center will cooperate with the feeding industries involved. Each feeding industry involved must comply with the terms and conditions set by MPOB and government agencies. These feeding industries involved are the existing companies, such as suppliers of fertilizers, seedlings, dealers, etc. They will aid in efficiently running the operation with the existing experiences and skills that could be offered by the feeding industries involved.

\section{FUND MANAGEMENT MODEL}

This section explains the fund management model. This section includes the sources of fund, the costs involved, the uses of fund, the contracts used, and the flow of this fund management model.

\subsection{Sources of Funds}

The sources of fund for the Islamic Microfinance for the palm oil sector could be obtained from the cash zakat funding, cash awqaf, Islamic Bank, government funds, and other donors, including retained earnings from the profit reaped by independent smallholders. In fact, many studies have looked into integrating zakat and awqaf in Islamic microfinance. Moreover, the economic empowerment programs of Baitul Maal Muamalat Indonesia (BMMI) and Baitul Qiradh of Badan Amil Zakat Nasional have already implemented the integration of zakat and microfinance. Both programs focus on the microfinance initiated, as well as utilize zakat and Islamic charities as sources of fund for microfinance practice (Yumna, A., Clarke 2011). Besides, Hassan (2010) 
pointed out a model of integration between zakat and awqaf fund in Islamic microfinance.

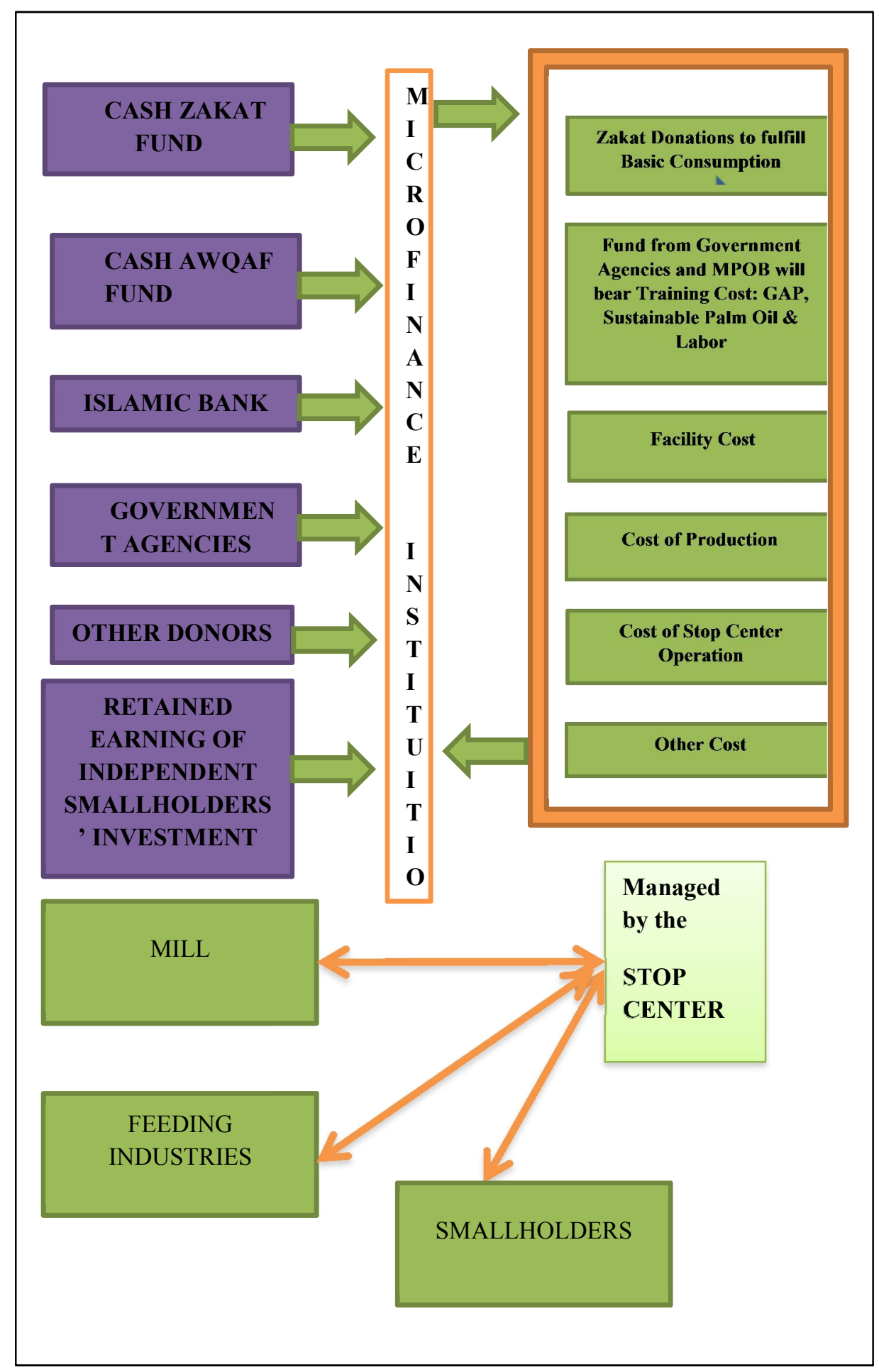

Figure 3. Fund Management Model 


\subsection{Costs Involved and Uses of Fund}

The costs involved in this mechanism comprise of cost of capital, facility cost, cost of production, operation cost of stop center, training cost for sustainable palm oil and Good Agricultural Practice (GAP), training cost for labor, and other costs. Zakat fund is only used for basic consumption and will only be granted to those qualified to receive the fund. This is because; some small-scale farmers might not be qualified to be the recipients of the fund. Then, government agencies and MPOB will bear the training costs for sustainable palm oil, Good Agricultural Practice (GAP), and for labor. Nonetheless, these independent smallholders would still have to pay for these costs. Thus, cash awqaf fund, fund from Islamic Bank, other donors' funds, and the independent smallholders' retained earnings from investment would be used to bear facility cost, cost of production, cost of stop center operation, and other costs.

In addition, the stop center will be responsible for administration and distributing the fund to the independent smallholder group. The fund will be classified into two parts: i) the fund used to bear joint costs, and ii) the fund used to bear utilization cost/per smallscale farmers. The fund that is used in partnership is for the cost to be shared equally by the group of independent smallholders, such as cost of facility like machinery and storage, cost of stop center operation, and so on. Meanwhile, the fund used to bear utilization cost per small-scale farmers is the cost that involves the cost difference between one farmer and another, such as the total amount of fertilizers, seedlings, pesticides, and the total area of farm that needs to be improved, based on the total span or the needs of the respective independent smallholder farm. This is to ensure parity among the independent smallholders, where they only need to repay the loan consistent with the supposed total, based on the actual cost used for every independent smallholders. This is to avoid loss and unfairness to the independent smallholders with small land, as well as to safeguard the welfare of all farmers involved. For that reason, a team of experts conducted a research for every farm involved, to determine the cost that they had needed, in estimation. The farmers were briefed about the costs involved and the total amount of loan that they might require.

\subsection{Contracts Used}

There are two types of contract that are applicable this model. First is Al-Qardhul Hasan. Al-Qardhul Hasan simply means an interest-free loan. The word 'Hasan', as understood in the context of 'ihsan', is meant to imply that the transaction is possible only when a person is fully aware that he or she is applying for a loan to someone in need without expecting anything in return from him or her, but only in order to please Allah (Mirakhor, A., Iqbal 2007). Islamic microfinance can provide Al-Qardhul Hasan Investment fund. The Al-Qardhul Hasan concept is usually used for current account product, instead of wadiah current account, to replace treasury bills offered by the Central Bank, and as a combination with other concepts in various products (Saad 2012). 
Second is Mudharabah. Mudharabah General Investment account is a savings account that can be used by the Mudarib/bank for the purpose of investment, where Mudarib/bank is not restricted to any condition; as the Mudarib/bank is authorized to do anything, which is normally done in the course of business. For instance, Rabbul Mal invested their money based on the al-Mudharabah al-Mutlaqah concept (Tahir, H.M., Ahmad 2009). In fact, this kind of contract can be adapted for investment activity in the form of the independent smallholders' saving, which can be used by the Islamic microfinance.

\subsection{Flows of the Fund}

The flows of fund under the model are explained by the steps below:

i. Islamic microfinance will raise funds from sources, such as zakat, Awqaf cash, Islamic banks, government agencies, other donors, and also earnings from independent smallholders' investment. The Islamic microfinance will provide funding to independent smallholders in accordance to the Al-Qardul Hasan loan contract. The funding will not be given directly to the farmers. Instead, the Islamic microfinance will channel the fund to the stop center. The funds will be separated in proportion to the costs involved, as depicted in Figure 3.

ii. After that, the fund will be managed by the stop center. This is to prevent the farmers from using the funding for unnecessary measures and this step enables a more organized system to be formed.

iii. Input supply, such as seedling, fertilizers, and delivery of FFB to the mill, will be managed by the feeding industries involved. Transaction of payments will be made after the FFB are sold. After FFB are sent to the mill, the mill will transact payments directly to the stop center. After that, the stop center will transact payments to the feeding industries involved.

iv. For revenue of independent smallholders, the stop center will audit all payments and deduct the total amount of debts to be paid; the total of agricultural zakat will be imposed if the nisab and haul for the farmers are sufficient for the zakat; and some percentages of the total amount of savings that need to be made by the independent smallholders, as dictated in the agreement. After the deduction process, the stop center will hand over the total amount of the remaining money to the farmers.

v. Then, the total savings would be transacted to the Islamic microfinance. The saving will be used by the Islamic microfinance for investment. In fact, the savings and investment methods have been adopted in the microfinance innovation in several countries, such as Syria and Sudan, which is known as the Sanduq model (Mahieux, T., Zafar, O., Kherallah 2011). 
vi. All profits from the investment will be used to cover the cost of the stop center operation and facility cost. The excess of the profits will be used as reserve for any risk of loss or unexpected costs that have to be accommodated in the future.

vii. Depositors can make a withdrawal after 3 years of financing and they are not allowed to withdraw the total saving at once, as there should be a minimal amount of money in the savings account.

viii. Cost of operation for the stop center will be covered by the dividend from the savings generated by the independent smallholders; whereas ujrah will be charged to the feeding industries and mills involved. Payments that are being held by the stop center before given to the feeding industries and the independent smallholders involved will also be generated to gain profit.

\section{CONCLUSION}

The fast-growing demand and production of palm oil have positive impact on economic growth of producers' countries. Hence, to ensure the production will not worsen future generations, sustainable farming is proposed. However, this farming technique may involve higher costs to the smallholders, specifically to the independent smallholders. Therefore, this study aims to create a sustainable mechanism framework of palm oil farming among smallholders using Islamic micro financing. Using descriptive approach, this study found that there are constraints and challenges faced by independent smallholders to create sustainable oil palm farming. This study also discovered that Islamic microfinance is indeed a possible source of funding for a number of independent oil palm smallholders. Hence, Islamic microfinance may contribute to sustainable palm oil production to develop a workable mechanism.

With the mechanism, hopefully it will resolve the issue of sustainability among oil palm smallholders. With the creation of stop center and financial assistance provided by the Islamic microfinance, hopefully, it can smoothly aid the operations of independent smallholders concerning oil palm productions, as well as to achieve these objectives. Besides, this strategy will allow multiple operating costs that can be supported in the long term and does not burden any party. More importantly, it can offer a win-win situation for all parties involved.

Acknowledgement: The authors gratefully acknowledge the support of Universiti Kebangsaan Malaysia under the Research Grant: EP-2018-001 (Dana Inisiatif Penerbitan FEP). 


\section{Reference}

Abas, R., Simeh, M.A., Abdullah, R., Hassan, A. 2010. “A Study on the Perceptions of the Supervised Fertilizer Cluster (KBT) Members in the KBT Programme." Oil Palm Industry Economic Journal 10 (1): 14-25.

Abdullah, R. 2013. "Technical Efficiency of Independent Oil Palm Smallholders (ISH) in Peninsular Malaysia with Respect to Fertiliser and Land Size.” Oil Palm Industry Economic Journal 13 (2): 27-37.

ADB. 2008. Food Prices and Inflation in Developing Asia: Is Poverty Reduction Coming to an End? Manila: Asian Development Bank.

Arun, T., Hulme, D. 2009. "Finance for the Poor: The Way Forward? In D. Hulme \& T. Arun,, Microfinance: A Reader.” Abingdon.

Basiron, Y., Weng, C. K. 2004. "The Oil Palm and Its Sustainability." Journal of Oil Palm Research 16 (1): 1-10.

Brandi, C., Cabani, T., Hosang, C., Schirmbeck, S., Westermann, L., Wiese, H. 2013. "Sustainability Certification in the Indonesian Palm Oil Sector: Benefits and Challenges for Smallholders.” Bonn.

Casson, A. 2000. “The Hesitant Boom: Indonesia's Oil Palm Sub-Sector in an Era of Economic Crisis and Political Change."

Cromme, N., Prakash, A. B., Lutaladio, N., Ezeta, F. 2010. "Strengthening Potato Value Chains: Technical and Policy Options for Developing Countries.” In . Rome: Food and Agriculture Organization of the United Nations.

Dahari, N., Omar, I., \& Mansor, N. H. 2010. “Saluran Media-Massa Yang Efektif Dalam Pemindahan Teknologi Sawit Kepada Pekebun Kecil.” In Prosiding Persidangan Kebangsaan Pekebun Kecil Sawit 2010: Bersatu Meningkatkan Produktiviti Mapan, 169-90. Sarawak.

Dubois, O. 2008. "Making Sure That Biofuel Development Benefits Small Farmers and Communities." Unasylva 230 (59): 25-32.

Euler, M., Hoffmann, M.P, Fathoni, Z., Schwarze, S. 2016. "Exploring Yield Gaps in Smallholder Oil Palm Production Systems in Eastern Sumatra, Indonesia." 
Agricultural Systems 146: 111-19.

Fargione, J., Hill, J., Tilman, D., Polasky, S., Hawthorne, P. 2008. "Land Clearing and the Biofuel Carbon Debt." Science 319 (5867): 1235-38.

Hassan, M. K. 2010. “An Integrated Poverty Alleviation Model Combining Zakat, Awqaf and Micro-Finance." In Proceedings of Seventh International Conference The Tawhidi Epistemology: Zakat and Waqf Economy, 261-81. Malaysia: Institut Latihan Islam Malaysia.

Hulme, D., Mosley, P. 1996. Finance against Poverty. London: Rouledge.

IIED and ProForest. 2004. "Better Management Practices and Agribusiness Commodities.” London.

Ismail, A., Simeh, M. A., Noor, M. M. 2003. "The Production Cost of Oil Palm Fresh Fruit Bunches: The Case of Independent Smallholders in Johor." Oil Palm Industry Economic Journal 3 (1): 1-7.

Kessler J.J., Rood T., Tekelenburg T., Bakkenes M. 2007. "Biodiversity and Socioeconomic Impacts of Selected Agro-Commodity Production Systems." Journal of Environment and Development 16 (2): 131-60.

Khaleequzzaman, M., Shirazi, N. S. 2102. "Islamic Microfinance - An Inclusive Approach with Special Reference to Poverty Eradication in Pakistan." IIUM Journal of Economics, Management, Accounting 20 (1): 19-49.

Koh, L.P., Wilcove, D.S. 2007. "Cashing in Palm Oil for Conservation.” Nature 448: 993-94.

Lam, M.K., Tan, K.T., Lee, K.T., Mohamed, A.R. 2009. "Malaysian Palm Oil: Surviving the Food versus Fuel Dispute for a Sustainable Future." Renewable and Sustainable Energy Reviews 13 (6-7): 1456-1464.

Mahieux, T., Zafar, O., Kherallah, M. 2011. "Financing Smallholder Farmers and Rural Entrepreneurs in the Near East and North Africa." In IFAD Conference on New Directions for Smallholder Agriculture, 1-19. Rome, Italy.

Manaf, Z.A., Rahman, A.K.A., Halim, N.A.A., Ismail, S., Abdullah, R. 2013. "Assessment of the Oil Palm Seedlings Assistance Scheme on Fresh Fruit Bunch 
Yield and Income of Smallholders." Oil Palm Industry Economic Journal 13 (1): $35-44$.

Meyer, R. 2007. "Microfinance Services for Agriculture: Opportunities and Challenges." In International Conference "what Microfinance for Developing Countries' Agriculture?, 1-12. Paris, France.

Mirakhor, A., Iqbal, Z. 2007. "Qard Hasan Microfinance. , 64: April-June.” New Horizons 164 (2): 18-20.

Morduch, J. 2009. The Microfinace Schism. In D. Hulme \& T. Arun,, Microfinance: A Reader. Abingdon: Routledge.

Morvant-Roux, S. 2008. "What Can Microfinance Contribute to Agriculture in Developing Countries?" In International Conference "what Microfinance for Developing Countries' Agriculture?, 1-20. Paris, France.

MPOB. 2018. "MPOB Codes of Good Agricultural Practice for Oil Palm Estates and Smallholdings.” Malaysian Palm Oil Board (MPOB). 2018. http://www.mpob.gov.my/images/stories/pdf/CodesPractice_Estate.pdf.

Murphy, D.J. 2014. "The Future of Oil Palm as a Major Global Crop: Opportunities and Challenges." Journal of Oil Palm Research 26 (1): 1-24.

Nagiah, C., Azmi, R. 2012. “A Review of Smallholder Oil Palm Production: Challenges and Opportunities for Enhancing Sustainability - A Malaysian Perspective." Journal of Oil Palm \& the Environment 3: 114-20.

Naidoo, R., Malcolm, T., Tomasek, A. 2009. "Economic Benefits of Standing Forests in Highland Areas of Borneo: Quantification and Policy Impacts." Conservation Letters 2 (1): 36-45.

Nelson P.N., Wbb, M.J., Orrell, I., Rees, H.V., Banabas, N., Berthelsen, S., Sheaves, M., Bakani, F., Pukam, O., Hoare, M., Griffiths, W., King, G., Carberry, P., Pipai, R., McNeill, A., Meekers, P., Lord, S., Butler, J., Pattison, T., Armour, J., Dewhurs, C. 2010. Environmental Sustainability of Oil Palm Cultivation in Papua New Guinea. Canberra: Australian Centre for International Agricultural Research.

Nilsson, S. 2013. "Palm Oil - Towards a Sustainable Future?: Challanges and 
Opportunites for the Swedish Food Industry."

Omar, I., Dahari, N. 2009. "Enhancing Oil Palm Productivity through Participative Technology Transfer: Malaysian Experience." In Proceeding of Agriculture, Biotechnology \& Sustainability Conference, PIPOC International Palm Oil Congress MPOB, 337-65. Kuala Lumpur.

Rahman, A.K.A, Abdullah, R., Shariff, F. M., Simeh, M. A. 2007. "Islamic Microfinance: A Missing Component in Islamic Banking." Kyoto Bulletin of Islamic Area Studies 1 (2): 38-53.

Rahman, A.K.A, Abdullah, R., Shariff, F. M., Simeh, M. A. 2008. "The Malaysian Palm Oil Supply Chain: The Role of the Independent Smallholder." Oil Palm Industry Economic Journal 8 (2): 17-27.

Rahman, A.K.A., Abdullah, Simeh, M.A., Shariff, F.M. 2009. "Management of the Malaysian Oil Palm Supply Chain: The Role of FFB Dealers.” Oil Palm Industry Economic Journal 9 (1): 20-28.

Rist, L., Feintrenie, L., Levang, P. 2010. “The Livelihood Impacts of Oil Palm: Smallholders in Indonesia.” Biodiversity and Conservation 9 (4): 1009-24.

Robinson, D. 2000. "Certification in Communally Managed Forests: Perspectives from Mexico." Forests, Trees and People Newsletter, 2000.

Rowell, A., Moore, P.F. 2000. “Global Review of Forest Fires.” Gland.

RSPO. 2010. "RSPO Principles and Criteria for Sustainable Palm Oil Production: Guidance for Independent Smallholders under Group Certification.” 2010.

Saad, N.M. 2012. "Microfinance and Prospect for Islamic Microfinance Products: The Case of Amanah Ikhtiar Malaysia.” Advances in Asian Social Science 1 (1): 27-33.

Tahir, H.M., Ahmad, S. 2009. Aplikasi Fiqh Muamalat Dalam Sistem Kewangan Islam. Shah Alam: Pusat Penerbitan Universiti Universiti Teknologi MARA.

Teoh, C.H. 2010. Key Sustainability Issues in the Palm Oil Sector. A Discussion Paper for Multi-Stakeholders Consultations (Commissioned by the World Bank Group). Washington DC: World Bank \& International Finance Corporation. 
Thongrak, S., Kiatpathomchai, S., Kaewrak, S. 2011. "Baseline Study of the Oil Palm Smallholders in the Project Areas: Final Report.” Bangkok.

Tincliffe, H., Webber, D. 2012. "Orangutans, Deforestation and the Problem of Palm Oil." Chemical Engineer 858/859: 24-25.

Tohiran, K. A., Raja Omar, R. Z., Omar, W., \& Johari, M. A. 2010. “Integrasi Bebiri Rerambut Barbados Blackbelly dengan Sawit Di Kawasan Gambut Secara Semi Intensif: Kajian MPOB.” In Prosiding Persidangan Kebangsaan Pekebun Kecil Sawit 2010: Bersatu Meningkatkan Produktiviti Mapan, 144-66. Miri Sarawak.

Vermeulen, S., Goad, N. 2006. Towards Better Practice in Smallholder Palm Oil Production. London: International Institute for Environment and Development.

Yumna, A., Clarke, M. 2011. "Integrating Zakat and Islamic Charities with Microfinance Initiative in the Purpose of Poverty Alleviation in Indonesia." In 8th International Conference on Islamic Economics and Finance: Sustainable Growth and Inclusive Economic D, 1-18.

Yunus, M. 2005. Banker to the Poor: Micro-Lending and the Battale against World Poverty. New York: Public Affairs Books. 